\title{
Cytotoxic and anti-inflammatory effects of chitosan and hemostatic gelatin in oral cell culture
}

\author{
Jessica J. Narvaez-Flores' ', Gabriela Vilar-Pineda², Laura S. Acosta-Torres', \\ Rene Garcia-Contreras ${ }^{1}$
}

1. Universidad Nacional Autónoma de México, Escuela Nacional de Estudios Superiores Unidad León, Laboratorio de Investigación Interdisciplinaria, Área de Nanoestructuras y Biomateriales, León, Guanajuato, México 2. Universidad Nacional Autónoma de México, Escuela Nacional de Estudios Superiores Unidad León, Área de Cirugía Oral y Maxilofacial, León, Guanajuato, México

\begin{abstract}
Chitosan is a biopolymer with bactericidal/bacteriostatic effect, biocompatible and biodegradable. It has been used in tissue engineering to replace tissues partially or completely by releasing bioactive materials or influencing cell growth, usually in regenerative medicine and dentistry. The aim of this study was to evaluate the cytotoxic and anti-inflammatory effect of chitosan

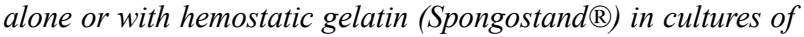
human pulp cells (HPC), human gingival fibroblasts (HGF) and mouse pre-osteoblasts (MC3T3-E1, ATCC). HPC and HGF were isolated from patients. Cells were subcultured in DMEM. Chitosan was inoculated at different concentrations (0-0.5\%) and hemostatic gelatins impregnated with chitosan (0.19\%) were placed directly in the presence of cells and incubated for 24 hours. Cell viability was determined by MTT method and mean cytotoxic concentration $\left(C C_{50}\right)$ was calculated from the dose-response curve. Anti-inflammatory effect was calculated from the in vitro gingivitis model induced with interleukin lbeta $(I L-1 \beta)$ in HGF and protein detection. The data were subjected
\end{abstract}

to Shapiro-Wilk, Kruskal-Wallis and Mann-Whitney tests. Experiments were performed in triplicate of three independent assays. Cell viability of HPC, HGF and MC3T3-E1 in contact with chitosan decreased significantly $(p<0.05)$. The HPC were the most sensitive $\left(C C_{50}=0.18 \%\right)$, followed by $\mathrm{HGF}\left(C C_{50}=\right.$ $0.18 \%)$ and MC3T3-E1 $\left(C C_{50}=0.19 \%\right)$. The cytotoxicity of gelatins impregnated with chitosan decreased cell viability of HGF and HPC by $11 \%$ and 5\%, respectively. The proinflammatory effect was reduced significantly in the gingivitis model. To conclude, chitosan induces moderate cytotoxic effects alone or with hemostatic gelatin at $0.19 \%$, in dose-dependent manner, with anti-inflammatory effects on human gingival fibroblasts. The use of chitosan as a biomaterial can be an excellent choice for use in regenerative dentistry.

Received: March 2021; Accepted: July 2021.

Keywords: chitosan - gingivitis - anti-inflammatory agents prostaglandin-E synthases - regenerative medicine.

\section{Efectos citotóxicos y antiinflamatorios del quitosano y la gelatina hemostática en cultivo celular oral}

\begin{abstract}
RESUMEN
El quitosano es un biopolímero con efecto bactericida/bacteriostático, biocompatible y biodegradable. Se ha utilizado en ingeniería de tejidos con el fin de reemplazar parcial o completamente los tejidos como material bioactivo o influyendo en el crecimiento celular, comúnmente, para medicina y odontología regenerativa. Evaluar el efecto citotóxico y antiinflamatorio

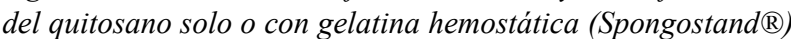
en cultivos con células pulpares humanas (HPC), fibroblastos gingivales humanos (HGF) y preosteoblastos de ratón (MC3T3-E1, ATCC). HPC, HGF se aislaron de pacientes. Las células se subcultivaron en DMEM. Se inoculó quitosano a diferentes concentraciones (0-0,5\%) y se colocaron gelatinas hemostáticas impregnadas con quitosano $(0,19 \%)$ directamente en presencia de células y se incubaron durante 24 horas. La viabilidad celular se determinó mediante el método MTT y se calculó la concentración citotóxica media $\left(\mathrm{CC}_{50}\right)$ a partir de la curva dosis-respuesta. El efecto antiinflamatorio se calculó a partir del modelo de gingivitis in vitro inducido con interleu-
\end{abstract}

cina $1 \beta$ (IL-1 $\beta)$ en HGF. Los datos se sometieron a las pruebas de Shapiro-Wilk, Kruskal-Wallis y Mann-Whitney. Los experimentos se realizaron por triplicado de tres ensayos independientes. La viabilidad celular de HPC, HGF y MC3T3-E1 en contacto con el quitosano disminuyó significativamente la viabilidad celular $(p<0.05)$. Las HPC fueron las más sensibles $\left(C C_{50}=0,18 \%\right)$ seguido de $H G F\left(C C_{50}=0,18 \%\right)$ y MC3T3-E1 $\left(C C_{50}=0,19 \%\right)$. Las gelatinas impregnadas con quitosano mostraron una disminución en la viabilidad celular para $H G F$, $H P C$ de $11 \%$ y $5 \%$ respectivamente y se redujo significativamente el efecto pro-inflamatorio en el modelo de gingivitis humano. El quitosano induce efectos citotóxicos moderados solo o con gelatina hemostática a $0,19 \%$ de forma dosis-dependiente con efectos antiinflamatorios en fibroblastos gingivales humanos. El uso de quitosano como biomaterial puede ser una excelente opción para su uso en odontología regenerativa. Palabras clave: quitosano - gingivitis - agentes antiinflamatorios - prostaglandina-E sintasas - medicina regenerativa. 


\section{INTRODUCTION}

State-of-the-art science promotes constant experimentation with different materials that are biocompatible with the human body, because innovation in dental biomaterials is essential to improving the practice of medicine and regenerative dentistry $^{1-3}$. Dental biomaterials are those materials used in regenerative $e^{4}$, prosthetic and reconstructive dentistry with the goal of replacing missing tissue as closely as possible to the original. To be considered acceptable, a biomaterial must be biocompatible, have good adhesion, have natural appearance similar to that of the missing tissue, be bioinert, bacteriostatic, bactericidal, and importantly, not cause toxic damage to the cells surrounding the tissue to be treated ${ }^{5,6}$. Chitosan is a biopolymer with bactericidal/bacteriostatic effects, biodegradable and biocompatible ${ }^{7}$, which has been used in tissue engineering to replace tissues partially or completely by releasing bioactive materials or influencing cell growth $^{7,8}$

Tissue regeneration is the answer for comprehensive restitution of body tissue after injury, unlike repair, where the scar tissue is formed with different features from the original tissue 9 . Every year, over 500,000 grafting procedures are performed to restore functionality following injuries such as bone fractures, injuries resulting from a variety of surgical, degenerative disease and traumatic causes that can be disabling or even cause loss of stability ${ }^{9,10}$. Bone and other tissue grafts have been an essential tool for rehabilitation in oral mucosa and other body parts because of their inductive capacity to regenerate damaged tissue caused by trauma or surgical treatment. Tissue engineering creates artificial grafts that are able to induce newformation and regeneration of soft and hard tissues through natural regeneration processes ${ }^{11}$.

Hemostatic gelatin is a product obtained during the degradation of collagen triple helical structure into single molecules. For years, gelatin has received much attention as a hemostatic material due to its excellent properties such as low antigenicity, biocompatibility, biodegradability and relatively low cost. Gelatins are also widely used in the sustained release of drugs and tissue engineering applications with bone, cartilage and $\operatorname{skin}^{12,13}$. It has been reported that gelatin can activate platelet aggregation and it is also used as an absorbable hemostatic agent ${ }^{14}$. The mixture of gelatin and polymers increases its chemical stability, improves mechanical properties and bioactive properties such as biocompatibility and antimicrobial effects. Chitosan has good filming and viscosity, contains free amino groups and can cross-link with gelatin ${ }^{15}$. These characteristics of gelatin and chitosan enable them to form a natural semi-interpenetrating polymer network among molecules and acquire porous properties similar to biological scaffolds ${ }^{15,16}$. However, few studies have been performed on the combination of chitosan and gelatin ${ }^{17}$.

Although some studies have been conducted on the cell cytotoxicity of chitosan ${ }^{7,18}$, the current study includes three different types of cell cultures. The objective of this research was to determine the cytotoxic and anti-inflammatory effects of chitosan alone or with an impregnated hemostatic gelatin scaffold (Spongostand $\AA$ ) in culture on human gingival fibroblasts (HGF), human pulp cells (HPC) and mouse pre-osteoblasts (MC3T3-E1), through a series of experiments of dose-response curve and expression of prostaglandin $\mathrm{E}_{2}\left(\mathrm{PGE}_{2}\right)$ with $\mathrm{MTT}$ and ELISA assays ${ }^{19,20}$. All assays were conducted at the Interdisciplinary Research Laboratory; Nanostructures and Biomaterials Area of the National School of Higher Studies, Unit León UNAM.

\section{MATERIAL AND METHODS \\ Cell culture}

The protocol was reviewed by the institution's bioethics committee for the patients' cell isolates and accepted under number CE_16/004_SN. All patients gave their permission for their extracted teeth to be used in this research.

To obtain human pulp cells (HPC) and human gingival fibroblast (HGF), non-pathologically damaged erupted third molars and gingival tissue were collected from healthy patients who underwent surgical odontectomy of third molars. After extraction, the samples were stored in Falcon ${ }^{\circledR}$ tubes with $10 \mathrm{~mL}$ of phosphate buffer saline (PBS, pH 7.4) and $1 \%$ antibiotic (Gibco ${ }^{\circledR}$, Grand Island, NY, EU). Each molar was cut at the cementoenamel junction with a carbide disc using a low-speed turbine under constant irrigation. The pulp and gingival tissue were obtained inside a laminar flow chamber (Lumistell®, Celaya Gto., Mexico) and explants of about $1 \times 1 \mathrm{~mm}$ were performed with scalpel blade \#20 in $60 \times 15 \mathrm{~mm}$ culture dishes (Thermo Fisher 
Scientific, Rochester, NY, EUA). The explants were inoculated into sterile $100 \times 15 \mathrm{~mm}$ culture dishes (Thermo Fisher Scientific) with DMEM culture medium supplemented with $20 \%$ Fetal Bovine Serum (FBS, Gibco $\left.{ }^{\circledR}\right), 1 \%$ antibiotic $(10,000 \mathrm{UI} /$ $\mathrm{mL}$ penicillin $\mathrm{G}$ and $10,000 \mu \mathrm{M} / \mathrm{mL}$ streptomycin sulfate, Gibco ${ }^{\circledR}$ ), and $1 \%$ Glutamax (Gibco $\left.{ }^{\circledR}\right)$. They were incubated at $37^{\circ} \mathrm{C}$ with $5 \% \mathrm{CO}_{2}$ and $95 \%$ humidity (Binder, Tuttlingen, Germany) for 3 weeks until a cellular confluence monolayer of $80 \%$ was obtained. The culture medium was replaced every third day after the first week. Mouse pre-osteoblast cells (MC3T3-E1, mouse C57BL/6 calvaria) were obtained from a certified strain (ATCC ${ }^{\circledR}$ CRL-2593) and sub-cultured in DMEM culture medium added with $10 \%$ FBS, $1 \%$ antibiotic and $1 \%$ Glutamax. Cells were sub-cultured in a range of $2 \times 10^{5}$ cells $/ \mathrm{mL}$ for each experiment.

\section{Chitosan and gelatin preparation}

Chitosan was prepared from shrimp shells $0.1 \mathrm{gr} / 10 \mathrm{~mL}$ ( $<75 \%$ deacetylation, Sigma Aldrich, Toluca, Mexico), mixed and stirred with $1 \%$ acetic acid. The mixture was left stirring on the heating and stirring grill at room temperature for 24 hours until it was homogenized and viscous-looking. The chitosan was prepared at $0.19 \%$ and the hemostatic gelatin (Spongostan ${ }^{\circledR}$, Ethicon, Johnson-Johnson, Belgium) was impregnated.

\section{Cell Viability}

HPC, HGF and MC3T3-E1 were sub-cultured in DMEM medium at $2 \times 10^{5}$ cells $/ \mathrm{mL}$ in $96-w e l l$ dishes and incubated for $48 \mathrm{~h}$ at $37^{\circ} \mathrm{C}$ with $5 \%$ $\mathrm{CO}_{2}$ and $95 \%$ humidity. Chitosan was inoculated at different concentrations in a range of $0-0.5 \%$ and incubated for $24 \mathrm{hrs}$. In case of hemostatic gelatin impregnated with $0.19 \%$ chitosan, the cells (HPC and HGF) were inoculated in a 24-well plate and the scaffolds were placed in direct contact for 24 hours. A control group of scaffolds was mixed with saline solution. Finally, the culture medium was removed and replaced by MTT reagent $(0.2 \mathrm{mg} / \mathrm{mL}$, thiazolyl Blue Tetrazolium Bromide, 98\% Sigma Aldrich), incubated for 7 hours, and the crystals of formazan were dissolved with dimethyl sulfoxide $\left[\left(\mathrm{CH}_{3}\right)_{2} \mathrm{SO}\right.$, DMSO, J.T Baker, USA]. The plate was analyzed in a microplate spectrophotometer (Thermo Scientific Multiskan GO) at $570 \mathrm{~nm}$ wavelength. The cells of the 24-well plate were transferred to 96 -well plates to analyze mitochondrial metabolic activity. Each test was performed in triplicate for each of the three independent experiments.

\section{Anti-inflammatory activity}

HGF was sub-cultured as described above in 24well plates. Interleukin-1 $\beta$ (recombinant human IL-1 $\beta,>97 \%$ Purity, R\&D Systems, Minneapolis, $\mathrm{MN}$, USA) reconstituted with albumin (Bovine Albumin Solution, 22\%, IMMUCOR GAMMA, Norcross, GA, USA) was used to induce cells to a pro-inflammatory state $(3 \mathrm{ng} / \mathrm{mL})$ and use them as a positive control for $3 \mathrm{~h}^{19,20}$. Then, the hemostatic gelatin scaffolds impregnated with chitosan at $0.19 \%, 1 \%$ and saline solution were inoculated in 24-well plates and incubated for a further 24 hours. The culture medium supernatant was stored in Eppendorf tubes, and prostaglandin $\mathrm{E}_{2}\left(\mathrm{PGE}_{2}\right)$ expression was analyzed with an expression kit (R\&D Systems) with ELISA tests, following the manufacturer's instructions.

\section{Statistical analysis and data expression}

Means, standard deviations and percentages were calculated. The data were analyzed with ShapiroWilks normality test, paired Student t-test to compare incubation times of cell proliferation, and ANOVA post hoc Tukey test. Significance was set at 0.05 and reliability coefficient $95 \%$.

\section{RESULTS}

All the data were adjusted to normal distribution.Fig. 1 summarizes the dose-response curve of the cytotoxic activity of chitosan from 0 to $0.5 \%$. The viable cell number was reduced significantly. The results from most to least sensitive to contact with chitosan were $\mathrm{HPC}\left(\mathrm{CC}_{50}=0.11 \pm 0.04 \%\right)<\mathrm{HGF}\left(\mathrm{CC}_{50}=0.19 \pm 0.02 \%\right)$ $<\mathrm{MC} 3 \mathrm{~T} 3-\mathrm{E} 1\left(\mathrm{CC}_{50}=0.19 \pm 0.03 \%\right)$.

The direct contact of hemostatic gelatin scaffolds impregnated with chitosan at $0.19 \%$ showed a cell viability as follows: HPC: Control (Saline solution $)=94.98 \pm 1.55 \%$, Chitosan $0.19 \%=89.14 \pm 0.57 \%$; HGF: Control (Saline solution) $=61.43 \pm 2.98 \%$, Chitosan $0.19 \%=11.90 \pm 0.04 \%$. The contact with HGF significantly reduced the viable cell number $(p<0.05$, Student- $t$ test, $n=9)$.

The individual cell viability tests were conducted using MTT on the HGF with hemostatic scaffolds (Fig. 2A) impregnated with chitosan or physiological solution for the control group, with and without 


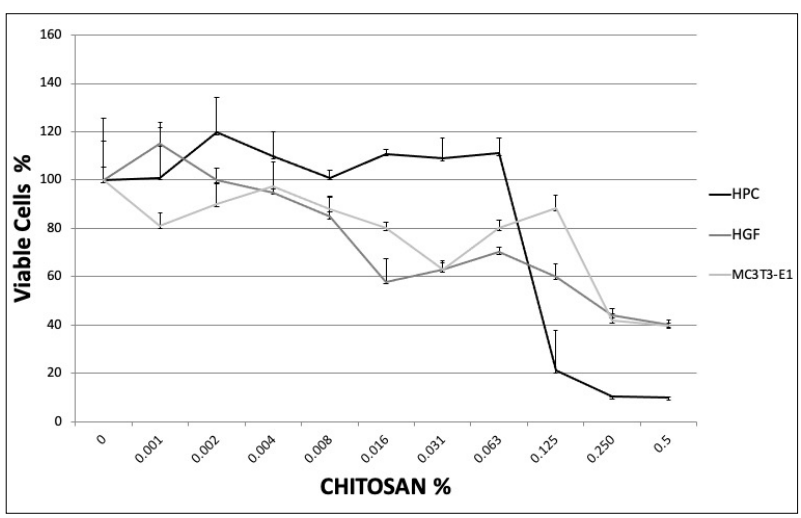

Fig. 1: Cytotoxic activity of chitosan in culture with HGF, HPC, MC3T3-E1 for 24 hours of incubation. The relative viable cell number was determined by the 3-[4,5-dimethylthiazol-2yl]-2,5-diphenyltetrazolium bromide assay. Each value represents the mean \pm S.D. of triplicate assays, ${ }^{*} p<0.05$ paired Student-t test (Intragroup), ANOVA Tukey test (Intergroup), $n=9$.

IL-1 $\beta$. An increase in cell viability of $106.91 \%$ was observed in chitosan with IL-1 $\beta$. Then, a test was performed with prostaglandin $\mathrm{E}_{2}$ and ELISA analysis. The following results were observed with the tests used to measure the pro-inflammatory effects using Prostaglandin $\mathrm{E}_{2}\left(\mathrm{PGE}_{2}\right)$ : the cells that were inflammed with IL-1 $1 \beta$ expressed a greater amount of $\mathrm{PGE}_{2}$ alone and with physiological solution, while in contact with Chitosan $0.19 \%$ and $1 \%, \mathrm{PGE}_{2}$ expression was reduced significantly $(\mathrm{p}<0.05)$ (Fig. 2B).

\section{DISCUSSION}

Other studies prior to ours have shown that chitosan has healing and antimicrobial effects. A systemic study conducted in Madrid on its cytotoxicity established that the lethal dose in rats (LD50) was $16 \mathrm{~g} / \mathrm{kg}$. The healing and bactericidal effect of chitosan has also been proven in studies conducted in Peru and Mexico ${ }^{2,6,21}$.

There is a need for new regeneration techniques for the oral mucosa -different from the tissue grafts used currently- which would be suitable for use in humans and applicable in restorative dentistry and oral surgery. The natural biopolymer chitosan satisfies these needs. Mexico is one of the countries with the most coasts and production of crustaceans from which chitosan can be obtained ${ }^{2}$, opening a broad panorama in terms of producing chitosan for regeneration techniques.

Our research team at the ENES Leon of the UNAM set itself the task of testing, standardizing and investigating the cytotoxic effects of chitosan in contact with human gingival fibroblasts (HGF), human pulp cells (HPC) and mouse osteoblasts (MC3T3.E1). HGF and HPC are common in the oral cavity. When they were placed in contact with chitosan -both in solution and in hemostatic sponges - in vitro, mean cytotoxicity concentration $\left(\mathrm{CC}_{50}\right)$ was found to be $0.19 \%$. It has been shown that Schwann cells and endothelial cells enhance attachment, proliferation, and survival rates ${ }^{22}$.
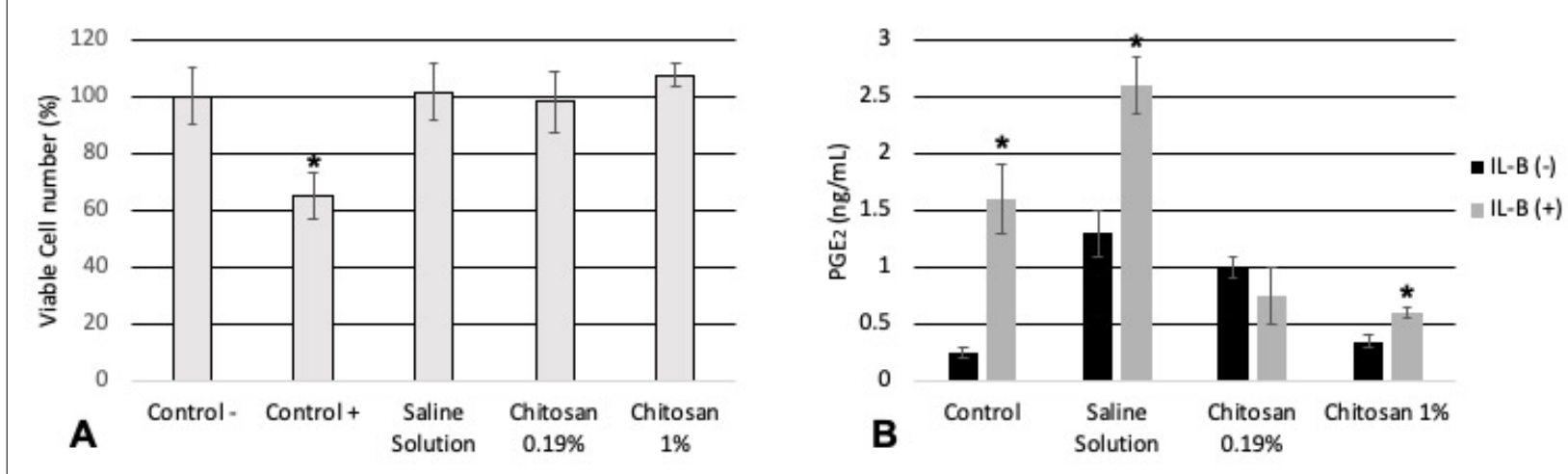

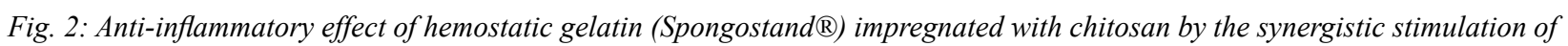
$P G E_{2}$ production with $I L-1 \beta$. A) Near confluent $H G F$ cells were pre-treated to induce inflammation for $3 \mathrm{~h}$ with $I L-1 \beta(3 \mathrm{ng} / \mathrm{mL})$ and incubated for a further 24 hours. The relative viable cell number was determined by the 3-[4,5-dimethylthiazol-2yl]-2,5-diphenyltetrazolium bromide assay. B) The concentration of PGE in the culture medium was determined by ELISA, to induce cells to a pro-inflammatory state $(3 \mathrm{ng} / \mathrm{mL})$ and use it as a positive control for three hours. Each value represents the mean $\pm S . D$. by triplicate assays. ${ }^{*} p<0.05,{ }^{* *} p<0.01$ paired $t$-test, $n=9$. 
With regard to anti-inflammatory effect, it has been shown that chondrocytes cultured in chitosan alginate beads reduce the expression of inflammatory cytokines (IL-6 and IL-8) and increase cartilage matrix component (hyaluronan and aggrecan) synthesis in vitro, in comparison to alginate beads alone ${ }^{23}$. Moreover, chitosan scaffolds have been found to inhibit the release of IL- $1 \beta$ and thus the formation of inflammasomes in mouse and human macrophages in vitro ${ }^{24}$. Here, we reported the potential anti-inflammatory effect by reducing the $\mathrm{PGE}_{2}$ released form human gingival fibroblast previously induced to gingivitis.

As mentioned in our hypotheses, at chitosan concentrations greater than $0.19 \%$ in contact with human pulp cells (HPC), human gingival fibroblasts (HGF) and mouse osteoblasts (MC3T3-E1), chitosan produces cytotoxic effects; however, at concentrations $<0.19 \%$, cell viability is higher in these cell lines, where at the same time their natural biopolymer characteristics continue to be maintained, as well as their recently known antiinflammatory effect. The current research studied properties of chitosan related to uses in medicine, and now dentistry. In the future, formulations could be based on the knowledge gained. Chitosan as a single biomaterial or in combination with other

\section{DECLARATION OF CONFLICTING INTERESTS}

The authors declare no potential conflicts of interest regarding the research, authorship, and/or publication of this article

\section{FUNDING}

This work was supported by Grants from PAPIIT-UNAMDGAPA: IA204516

\section{REFERENCES}

1. Agulló E, Mato R, Peniche C, Tapia C, et al. Quitina y Quitosano: obtención, caracterización y aplicaciones. Fondo editorial de la Pontificia Universidad Católica del Perú, Lima, Perú, Plenum Press, 2004.

2. Martinez-Sanchez. H, Escobedo A, Vazquez A. Elaboración de un gel biodegradable a base de quitosano con efecto cicatrizante. Virtualpro:Biopláticos 2013; 138:1-10.

3. Hirano H, Seino Y, Akiyama Y, Nonaka Y. Chitosan: a biocompatible material for oral and intravenous administration. In: Gebelein C.G., Dunn R.L. (eds) Progress in Biomedical Polymers, Springer, Boston, USA. 1990.

4. Ophof R, Van Reheden REM, Von den Hoff JW, Schalkwijk J, Kuiipers-Jagtman AM. Oral keratinocytes cultured on polymers could provide great improvements in tissue engineering and regenerative medicine, by providing a safe, affordable alternative for any type of condition, and helping to improve healing in situations such as oral surgery, periodontics, implantology, or any other requiring optimal, safe grafts. In the future, more studies will focus on the preparation of chitosan scaffolds via 3D printing and cryogelation methods to facilitate the application of chitosan in biomedicine. Chitosan, as a part of any material, could introduce valuable properties such as antimicrobial activity, mucoadhesion, and biocompatibility, which are required properties for a regenerative biomaterial.

Our results indicate that chitosan at concentrations above $0.19 \%$ can induce cell death or decrease cell viability when in direct contact with human pulp cells (HPC), human gingival fibroblasts (HGF) and MC3T3-E2. However, at concentrations lower than or equal to $0.19 \%$, it induces cell viability and does not cause cytotoxicity, at the same time having a significant anti-inflammatory effect. Considering both the findings and the limitations, a new potential application of chitosan using a hemostatic gelatin scaffold for formulations in regenerative dentistry is proposed.

\section{CORRESPONDENCE}

Dr. Rene Garcia-Contreras

Área de Nanoestructuras y Biomateriales

Escuela Nacional de Estudios Superiores, Unidad León

Universidad Nacional Autónoma de México

Boulevard UNAM No 2011, Predio el Saucillo y el Potrero, 36969

León, Guanajuato, México.

rgarciac@enes.unam.mx dermal matrices form a mucosa-like tissue. Biomaterials. 2002;23:3741-3748.

5. Ueda M, Ebata K, Kaneda T. In vitro fabrication of bioartificial mucosa for reconstruction of oral mucosa: Basic research and clinical application. Ann Plast Surg. 1991;27:540-549.

6. Harris R, Quitosano. Un biopolímero con aplicaciones en sistemas de liberación controlada de fármacos. Universidad Complutense de Madrid. Madrid, España 2009.

7. Aranaz I, Mengibar M, Harris R, Paños I, Miralles B, Acosta N, Galed G, Heras A. Functional characterization of chitin and chitosan. Current Chemical Biology. 2009;3:203-230.

8. Khan A, Wang B, Ni Y. Chitosan-nanocellulose composites 
for regenerative medicine applications. Curr Med Chem. 2020;27:4584-4592.

9. Garner WL. Epidermal regulation of dermal fibroblast activity. Plast Reconst Sur. 1998;102:135-139.

10. Civitelli R, Beyer EC, Warlow PM, Robertson AJ, Geist ST, Steinberg TH. Conexin 43 mediates direct intercellular communication in human osteoblastic cells networks. J Clin Invest. 1993;91:1888-1896.

11. Sultankulov B, Berillo D, Sultankulova K, Tokay T, Saparov A. Progress in the development of chitosanbased biomaterials for tissue engineering and regenerative medicine. Biomolecules. 2019;9:470.

12. Dolci E, Gay EC, Arnabat DJ. La prevención de la Alveolitis seca. Rev Eur Odontol Estomatol. 1992;5:261-270.

13. Liu Y, Shu XS, Prestwich GD. Osteochondral defect repair with autologous bone marrow-derived mesenchymal stem cells in an injectable, in situ, cross-linked synthetic extracellular matrix. Tissue Eng. 2006;12:3405-3416.

14. Alizadeh A, Abbasi F, Khoshfetratc AB, Ghaleha H. Microstructure and characteristic properties of gelatin/ chitosan scaffold prepared by a combined freeze-drying/ leaching method. Mater Sci Eng C. 2013;33:3958-3967.

15. Wang T, Turhan M, Gunasekaran S. Selected properties of pH-sensitive, biodegradable chitosan-poly (vinyl alcohol) hydrogel. Polym Int. 2004;53:911-918.

16. Sarem M, Moztarzadeh F, Mozafari M. How can genipin assist gelatin/carbohydrate chitosan scaffolds to act as replacements of load-bearing soft tissues? Carbohydr Polym. 2013;93:635-643.

17. Lan G, Lu B, Wang T, Wang L, Chen J, Yu K, Liu J, Dai F, Wu D. Chitosan/gelatin composite sponge is an absorbable surgical hemostatic agent. Colloids Surfaces B:
Biointerfaces. 2015;136:1026-1034.

18. Kunkel SL, Wiggins RC, Chensue SW, Larrick J. Regulation of macrophage tumor necrosis factor production by prostaglandin E2. Biochem Biophys Res Commun. 1986;137:404-410.

19. Garcia-Contreras R, Scougall-Vilchis RJ, ContrerasBulnes R, Kanda Y, Nakajima H, Sakagami H. Induction of prostaglandin $\mathrm{E}_{2}$ production by $\mathrm{TiO}_{2}$ nanoparticles in human gingival fibroblast. In Vivo. 2014;28:217-22.

20. Garcia-Contreras R, Sugimoto M, Umemura N, Kaneko M, Hatakeyama Y, Soga T, Tomita M, Scougall-Vilchis RJ, Contreras-Bulnes R, Nakajima H, Sakagami H. Alteration of metabolomic profiles by titanium dioxide nanoparticles in human gingivitis model. Biomaterials. 2015;57:33-40.

21. Leon K, Santiago J. Propiedades antimicrobianas de películas de quitosano-alcohol polivinilico embebidas en extracto de sangre de grado. Rev Soc Quim Perú. 2005;71:185-192.

22. Li G, Han Q, Lu P, Zhang L, Zhang Y, Chen S, Zhang $\mathrm{P}$, Zhang L, Cui W, Wang H, Zhang H. Construction of Dual-Biofunctionalized Chitosan/Collagen Scaffolds for Simultaneous Neovascularization and Nerve Regeneration. Research (Wash D C). 2020:2603048.

23. Oprenyeszk F, Sanchez C, Dubuc J-E, Maquet V, Henrist $\mathrm{C}$, Compère $\mathrm{P}$, Henrotin Y. Chitosan enriched threedimensional matrix reduces inflammatory and catabolic mediators production by human chondrocytes. PLoS ONE. 2015; 10:e128362

24. Vasconcelos DP, de Torre-Minguela C, Gomez AI, Águas AP, Barbosa MA, Pelegrín P, Barbosa JN. 3D chitosan scaffolds impair NLRP3 inflammasome response in macrophages. Acta Biomater. 2019;91:123-134 